\title{
Politico-cultural appropriation of Native American in American Indian poetry and drama: Unflinchingly documents the halfway existence
}

\author{
Shaista Malik*1 | Samar Zakki ${ }^{2}$ Dur-e-Afsha ${ }^{1}$ | Wajid Riaz ${ }^{3}$ \\ 1. Department of English Language and Literature, Hazara University, Mansehara, Pakistan. \\ 2. Department of English, National University of Modern Languages (NUML), Islamabad, Pakistan. \\ 3. Department of English Language and Literature, The University of Lahore, Sargodha, Pakistan. \\ *Corresponding Author Email: wijisami@ gmail.com
}

Published: September 22, 2021

\begin{abstract}
During the Twentieth century Native American literature evolved from anonymity into prominence by assuming a commitment to reflect the particular challenges that faced Native American people during last two centuries. Native American Literature illuminates about Native American lives, culture and how Indian values have changed from traditional tribal to mainstream ones that threatened tribal existence. The paper seeks to substantiate that this literature documents the horrible impact of brutal federal government on Indian's lives through policies and programs designed to subject them to degrading and confining existence both on physical and mental levels. The paper also seeks to prove that the Indians in order to adapt themselves to the mainstream Euro-American ways lost their old ones along the way but could not adopt mainstream American lifestyle. At the turn of the Twenty First century, because of the coercive strategies for assimilation, American Indians residing on reservations could not become a part of mainstream America but the way back to traditionalism was also farther away and irreversible. The paper also strives to substantiate that Native American literature documents and provokes Indians to assert their tribal identity by retaining many of the tribal ways and values.
\end{abstract}

Keywords: American Indian Literature, Euro-American Paternalism, Coercive Strategies, Tribalism, Mainstreaming.

How to Cite: Malik, S. Mumtaz, F., Afsha, D., \& Riaz, W. (2021). Politico-cultural appropriation of Native American in American Indian poetry and drama: Unflinchingly documents the halfway existence. Journal of Humanities, Social and Management Sciences (JHSMS), 2(1), 133-146. https://doi.org/10.47264/idea.jhsms/2.1.12

Publisher's Note: IDEA PUBLISHERS (IDEA Journals Group) stands neutral with regard to jurisdictional claims in the published maps and institutional affiliations.

Copyright: ( 2021 The Author(s), published by IDEA PUBLISHERS (IDEA Journals Group)

Licensing: This is an Open Access article published under the Creative Commons AttributionNonCommercial 4.0 International License (http://creativecommons.org/licenses/by-nc/4.0/) 
Politico-cultural appropriation of Native American in American Indian poetry and drama ...

\section{Introduction}

To understand the evolution of Native American literature, it is imperative to examine the chronicle of Native American's nations, which is studded with various phases of Separation, Coercive assimilation, Tribal restoration and Termination (Bachman, Death and Violence, 131). At the turn of the Nineteenth century, the U.S government confined a majority of Native population onto reservations ${ }^{1}$ and thereby exterminated all possibility for substantive armed opposition (Edmunds, 2001). In 1887, Congress passed Allotment Act (Dawes Act) ${ }^{2}$. This act essentially forced acculturation upon tribal people and aimed eventually to assimilate them into American society. Edmunds writes that most of the tribes ensconced on reservation were dependent upon the federal government for their economic wellbeing; hence, their lives were strictly circumscribed by federal policies. Divested of sovereignty and self-determination, these people were unable to chart their own scheme of action. Federal government policies were corroborated by the zeal of missionaries, and other "agents of acculturation" who travailed religiously to transform the mind-set of the Indian communities. These reformers believed that the potent way to transform Natives lies in the region of education. To help Indian children emerge as civilized and patriotic American citizen, children were processed through Boarding school system designed for acculturation.

Fixico states (2006) that these structural policies and legislations to forcibly assimilate the Natives shattered the family unit, which was not only a socio-cultural entity but the most important agent for sustaining and transmitting cultural values to posterity. However, with federal governmental interference concerning boarding schools, foster houses and tribal land allotments, people faced with a crisis and lost their way. These legislations demanded alteration in culture and doctrine, and it changed Indian families from communal lifestyle to individual one apart from displacing the people from the havens. Lost in midway, economically impoverished and culturally displaced, the Natives adopted a very different lifestyle characterized by alcoholism, unemployment, poverty, suicide and extreme violence.

\section{Literature review}

Since the publication of A House Made of Dawn by Momaday (1968), Native American Renaissance ${ }^{3}$ defines almost all literary activities carried out by the native writers. Kenneth Lincoln in Native American Renaissance suggests that Native American writers reclaim literary heritage produced by Native writers and also resurrect wonted tribal aesthetic expression like "mythology, ceremonialism, and the oral tradition of narrative transmission" (12). Paula Allen in Song of the Turtle also articulates that literature, by sustaining relationship to the people, to the lost heritage and by reconnecting to the tradition, affirms a people's continuation as a nation. By creating literature, like the story tellers of the past, the writer serves the people over and above themselves in an imperishable act of remembrance because, "Remembering is all" (7), she says. American Indian Literature commits this act of remembrance.

In Remembrance, Renewal, Geary Hobson (1983) writes that Native American literature is deep rooted into the community of which it is a reflection and five centuries of cultural assault failed to uproot it. In its early phase, Native American literature consisted of storytelling and oratory. But in later part of the nineteenth century, with the establishment of the Indian reservation system the autobiography and biography flourished as a genre and continued till the twentieth century. In the last quarter of the twentieth century, the Native American literature 
extended into fiction, journalism and even playwriting.

Initially these writers were concerned with identity issues. But, with the passage of time the Indian writers incorporated ideas of sovereignty by reclaiming the past. It became more imperative to these writers "to recognize their common heritage and strive together for the betterment of Native Americans as an entity" (Dennis, 2007). Few write about Reservation life, others portray urbanise milieu, some delve into history, and others are ferociously contemporaneous. A brief survey of the poetry and drama produced during the second phase of Native American Renaissance substantiates that literature created by writers like Sherman Alexie, F. Scott Momaday, Hanay Geiogamah, Yellow Robe, Roxy Gordon, Drew Taylor not only reclaim past heritage by re-establishing relationship with land, people and past, but it also truthfully depicts the horrific consequences of coercive assimilation faced by Native Americans. Most of these writers received mainstream education, beyond Indian Boarding schools and joined the mainstream of American life, yet they (almost all) have proudly retained their peculiar Indian identity and showed a beacon light to the readers and audience out of abysmal despondency.

\section{Paper}

A chief adherent of American Indian literary Renaissance Sherman Alexie (1966-) revived communal poetry which was meant to be chanted and performed with dramatic gestures. Helen Howard (1979) in his American Indian Poetry writes that the Indians like Chinese think and express themselves in symbols. A simple Indian word may represent an idea whose expression in English would require a whole sentence. His ideas must either be interpreted against a background of a myth or legend, or be supplemented by music, chants and dance postures and gestures. Sherman Alexie (1996) claims his Indian heritage by introducing an "inside song"4 in his poetry. Alexie has been criticised severely by his detractors for depicting stereotypical presentation of the native Indians, but Joseph Coulombe (2002) points that Alexie (1996; 2000)'s humour is "a key to the constructive social and didactics role manifested throughout his poetry". His humour on one hand exposes injustices and inequities; on the other hand, it heals wounds by defending self-esteem and nurture communal alliances. Keneth Lincoln (1993) in Indi'n Humour describes that Indian humour has "... the power to heal and harm, to bind and to exorcise, to reincarnate and to purge" (5). Alexie's convoluted humour unsettles schematic thinking patterns and compels re-evaluation and maturity, eventually compelling Indians to link up with their heritage in refreshing manner and pressuring non- native readers to reckon stereotyping and crude generalizations. In this way Alexie's brand of humour is capacious to facilitate mutual affection and esteem between various cultures. By blowing up expectations and forcing dialogue, humour instructs self-knowledge and social consciousness to both natives and non-natives.

A common running thread throughout his poetry is his depiction of reservation life as confining and degrading. Susan Brill thinks that Sherman Alexie's poetry constitutes:

"Anguish and humour, starvation and survival, affection and wrath, broken treatises, Imperialism, basketball, cockroaches, commodity food, HUD houses, smallpox blankets and promises and dreams".

Alexie (1996) establishes a further connection between the physical layout of the reservation 
Politico-cultural appropriation of Native American in American Indian poetry and drama ...

and the mental confinement it engenders in its inhabitant's lives. Alexie writes, making reference to the paltry, monotonous HUD houses ubiquitous on the reservation:

Foot by foot

We measure definitions

Assigned to us by years.

Alexie's characters, sadly, want nothing better than a temporary escape from their bitter reality through alcohol. Achieving immediate gratification is their aim in life.

He also has an insight into legal discrimination carried out in a xenophobic mainstream culture where black life is considered cheap in comparison with white life. The disregard for black life during the slavery era was no more brutal than that experienced by the Indians during the westward expansion. This is certainly validated by the virtual extinction of the entire American people. An oft-quoted saying regarding Indians is, "well, you know, the only good Indian is a dead Indian". Alexie highlights stringent and discriminatory behaviour and practice on the part of the justice system against American Indians. Indians have a high proclivity for being grasped for a crime, and encountering a more abrasive treatment for a similar offence. Hence in one of the poems "Capital Punishment" (The Summer, 86) he writes:

It's mostly the dark ones

Who are forced to sit in the chair $(1996)^{5}$

Alexie implies that America defines who kills whom and who is to be punished, because it's United States of America and "America fills its dictionary" by giving new definitions to the words. He further says:

And we'd have no idea for which of our sins

We were reduced to headlines and ash (1996)

In addition to many other problems for the Native Americans, they are living in a lethal atmosphere where racial slurs and slogans are a constant presence. "Wagon burners", "savages" "primitives" "man eaters", "red Indians" are the routine salutation meted to these people. These negative Indian stereotypes and racism are an exhibition of lack of understanding on the part of white culture who denigrates their culture and find them short of the standard set by themselves. Alexie in poem after poem draws attention to this denigration and aspersion of the Natives' culture and tradition. In "The Warriors" (1997) he accuses television for inculcating negative view about Indians,

"On television, white men were heroes and Indian men were savages. On television, Indian women were primitive and white women were gorgeous. I learned to hate my brown skin" (One Stick Song, 2001, 48).

In "Unauthorized Biography" he (2008) writes of a white boy who leans out of the window of his car and pours racial slurs on the Indian narrator by saying, "I hate you Indian motherfucker" (Alexie, 2000) and the narrator, helpless, in a white dominant culture quietly waits for the signal to turn green. 
American Indians may be experiencing culture conflict between dominant white culture and their own Indian identity. This is particularly true when an American Indian is struggling with both the usual identity problems of youth and the identity problems for being Indian in a white society- an identity which is too often confronted with negative stereotypes and discrimination in Mainstream American culture. Moreover, when this cultural conflict is played out in an environment riddled with such maladies as unemployment, poverty and social disorganization, the effects may be manifested in acts of lethal violence.

The helplessness and humiliation that are often associated with being poor were revealed many times in American Indian literature. The writers expressed exasperatedly of the economic oppression these people went through and bear on to experience today, for Alexie poetry is equal to "Anger x imagination" (2008). His "razor-like wittiness", attracts its attention to the torture, always acts to appease it, to make it bearable to the people provided with a few economic opportunities to thrive on reservations. Most were underemployed. With the structured reality of little economic opportunity and the cultural norms of 'paternal support' existing within the same context, it is not surprising that feeling of inadequacy and frustration could emerge and perhaps even lead to violent behaviours. Hence Alexie gives vent to his anger in "Sugar Town" (2000)

I prayed for food, for food!

Could that happen

In the United States of America?

Alexie's prayers are heard and his father enters with Kentucky Fried Chicken; an element of commodity food. Shaheena Bhatti in "Healing and the Enviornment" writes about Commodity food that "in second half of twentieth century, provision of food items like tinned meat, soups and juices; pasta; food grain; rice; cheese; peanut butter; corn soup; flour' dry concentrated milk; and vegetable oil" is the cause of obesity in American Indians at an alarming rate. The commodity food which is the cause of type 2 diabetes is also highest in Native Americans. For economically distressed and undernourished people, commodity food seems the best choice which provides maximum calories, which is tantamount to buying disease per dollar" (Bhatti, 293). Hence Alexie exhibits his concern with diabetes and related problems in "Sugar Town" where he commemorates his father who got amputated his foot because of diabetes. He says:

He reaches down in his dreams

To scratch the itch of the missing foot

Turned to ash in the wildfire of diabetes (2000)

In the same poem, Alexie further elaborates the link between low quality food and genetically as well as culturally transferred diabetes:

I am chasing my father

I am chasing my father's foot (1996)

Hence Alexie is afraid of "the donuts and candy bars" that he hides from his father for his house in reservation is riddled with "hypodermal needles and insulin bottles" (1996).

In another poem Alexie exhibits his fear of death and asserts: 
Politico-cultural appropriation of Native American in American Indian poetry and drama ...

I Only wanted to live

One day longer than you (2000)

The title poem "One Stick Song" is specifically induction of this custom, a recalling account/song which acts to repossess centuries of passing by locating people in living memory. Its repetitious chorale figures move towards a mood of revealing in which Alexie directs the reader to a view of a culture that is as lope from most famous constructs, a novel position on old methods that battles stereotypes while gathering an alternate identity which is obligating and coaxing in its bright gathering of life's imagination. Some of the writers also focus on homelessness in Native American community. Family as a place where love and affection abound, but some writers see it as a place where violence is most likely to occur. Verbal aggression and sexual assault among family members is certainly harmful. Strauss and Gelles write (1979):

"The alcohol is, of course ever-present, and you wonder, is alcohol the cause of the problem, or is it the result of everything that these people must live with like unemployment" (90).

Economic deprivation and political powerlessness also affect the propensity for American Indians population to direct aggression inwards in the form of suicide American Indian literature reflects the despair of ensnared and trapped mortals who direct violence and aggression not only outward rather inward. Alexie connotes that those individuals who have been harmed in an effort by the government to assimilate into the general attributes of American life, self-destruction could be interpreted as the eventual gesture of liberation. Suicide defies social control and challenges the dominant society's norms. According to Durkheim, "suicide is the ultimate act of defiance with regard to American Indian population. It is an unwillingness to continue suffering" (82). Durkheim elucidates that communities- intransition or in the process- of -acculturation are divested of the strong foothold of their tradition exhibit a higher rate of suicide. Underlying all this violence is the contact between Native Americans and mainstream white society, which caused cultural change. The whites being in control of deciding authorities were the dominant groups actively and deliberately meddling with the traditional Indian culture. With culture change, some Native American groups experienced loss of cultural traits without replacement as well as the inhibition of preexisting cultural patterns. Hence Alexie (2000) sings of his cousin in "One Stick Song", "who jumped off the bridge".

Native American writers are weary of the Radio-active activities done on or near reservation. All too often companies propose to bring jobs to Indian reservation, but only temporarily and then leave behind such things as toxic waste and environmental degradation. La Duke and Churchill term this process "radioactive colonization" (68). They describe several instances in which companies not only left Indian communities without jobs, but also left them with serious health threats. Excavation of uranium, oil and gas in reservation areas led these companies to hire tribal Indians in underground mining operations. These workers were given low wages, than the normal rate. When these uranium deposits were exhausted, the corporations had simply abandoned at the site some 71 acres of raw tailing' which retains $85 \%$ of the original radioactivity of the ore. This huge pile of tailings begins very close to the water source, which in case of many reservations are the only source of fresh water. The miners also worked underground at the facility. Many of them died of radiation, induced lung cancer or contracted 
respiratory maladies. Alexie remembers his grandmother and sings a song to commemorate his grandmother who was:

"heavy with tumours

O' bright explosion, crimson and magenta

O big grandmother, gold uranium and white X-ray (2000)

Alexie' (2000) s anger is manifested in many of his stories and poems. "The Powwow at the End of the World" is particularly an exhibit of Alexie's raw anger. The poem is a denunciation of crimes at the environment and against people. Alexie is not ready to forgive the white corporate culture which constructed Grand Collee Dam on Columbia River to produce hydroelectric power and provide irrigation water. Construction of this dam involved relocation of Native Americans whose lands were particularly flooded. This dam has blocked the migration of salmon and other fish upstream to spam. He blames this dam and inhuman white policies which forgot the people living at the mouth of the river, who after the construction of the dam were exposed to frequent floodwaters. He accuses the corporate culture for the extinction of Salmon fish which is not only the source of healthy food to the people; rather it is very important as a cultural signifier. The construction of the dam signifies end of the world for Alexie who says that he will forgive the white civilization only when "I am dancing with my tribe during the powwow at the end of the world." (2000).

In another poem, “The Mice War" Alexie speaks of the hatred taught to him by reservation.

"The Reservation had taught me to hate

... I beat the grass because it was grass. I

Hated the grass because the reservation

Had taught me to hate grass" (2000)

\section{American Indian drama}

Ann Huugo writes in "American Indian Theatre", unlike the Native American literature, the Native theatre Movement is a relatively recent phenomenon which occurred in the 1970s (Huugo, 189). Although, Native plays were not new to the performing arts in the twentieth century but before 1970s, Native artists or writers were rarely in control of this theatre. Early attempts to write for the theatre or to form companies mark important moves by Native artists to gain some control over public representation of their cultures and arts. Huugo associates the beginning of a discernible Theatre Movement with a shift "from an industry in which native creativity is controlled or directed by others, to an industry in which an increasing number of Native artists and writers exert creative control". In theatre, this transformation occurs in 1972 with Geiogmah's launch of the first successful Native Theatre Company, later known as NATE $^{6}$. Seventh Generation a collection of record of native plays by Indian and Canadian writers becomes an important milepost in the history of Native American literature. It signifies a journey from forgetfulness to remembrance and from silence to voice. The book is composed of seven plays and these all are true representation of the diverseness of theatrical manifestation of contemporary Native American issues. Christy Stanlake remarks, "it takes lots of voices to narrate a story... one voice doesn't suffice as we are what we are in kinship to others, and we each have our different ways of envisioning." The anthology captures the voices of seven writers who represent many Indian natives and who approach their work from differing 
Politico-cultural appropriation of Native American in American Indian poetry and drama ...

philosophies about the role of Native Indian theatre. A staunch supporter of active resistance, Hanay Geiogamah believes that "the theatre can really help us to stop the erosion of our Indian ways of life", and he foresees a time when all Indian nations would produce plays to recount tales about their people, culture and history.

In its premier show Body Indian was presented for the first time. It is a short play which takes place in five scenes and as a piece of art it is conventional. Bobby Lee, the protagonist wears an artificial leg, having lost his real leg after passing out on a track and being hit by a train. Bobby's physical malady and the train accident are both metaphors in the play for a dysfunctional society devoid of spiritual and physical energy. Physically damaged, Bobby Lee also leads a spiritually damaged life and being a type he can be taken for an everyman taking an everyman as audience toward enlightenment. Ronet Bachman's (1992) Death and Violence develops a nexus between political and economic conditions on reservation and violence in all its manifestation. Bachman sees the European conquest of Indian population typifies the process of "internal colonization" (37) which is the root cause of social disorganization, selfdestruction through alcoholism and suicide. So called "progressive" historical records claim innovation, exploration and discovery by Euro-Americans, whereas the actual reality speaks of a series of brutalization, exploitation, segregation, expulsion, and, for some tribes complete annihilation" (37). American Indians were forced to live in such a state of "frustration and blocked opportunities" (26) that both inward and outward forms of aggression were inevitable. In such a "fatalistic environment" the sanctitude of life, one's own and others' is depreciated. Body Indian by Geiogamah (1981) deals with a "holocaust" which has engendered death of not only a people but erasure of a whole culture. The Indians as a people are left with no heritage or identity and consequently they turn to drugs, alcohol and violence. The drama depicts that prescriptive moral, spiritual and religious restraints hold no significance for a community undergoing social derangement and deviation from cultural and ethical standards become not unimaginable for such a community.

In the play Body Indian Bobby Lee has received his allotment money and arrives at the apartment and announces that he hopes to use the allotment money to "check into rehab". The others persuade Bobby to keep drinking, and once he passes out, his "friends" repeatedly roll him violently for money, rifling through his clothes and eventually even taking his artificial leg to pawn it. As more and more of Bobby Lee's money disappear, the audience witness the gradual disintegration of hope for his future, though at first Bobby himself seems unaware of it. At each violation of Lee's body, we hear the train rolling down the tracks symbolizing American development as destructive of the native culture and people, but it also signifies violation and destruction of native people by their own community. Ann Huugu (1992) notes that train is a common symbol of destruction and colonization in Native literature. Bobby Lee delves deeper and deeper into destructive abyss at the end of the play from where there seems no hope to get out. Jeffrey huntsman (1998) states that the play's central theme is:

"The way Indian people in particular abuse, degrade, and cripple each other and themselves. The writer intends to direct questions to native audience more than non-natives. "Does the cycle of self destruction and victimization end? When will Bobby Lee recognise he is being preyed upon or doing the preying? In this light the play is not about alcoholism. Alcohol is just one dysfunctional element circulating through Bobby Lee's life" (93). 
The growing popularity of Native Theatre can be gauged from the fact that Hanay Geiogamah (1945-) with Taye Darby initiated project Hoop ${ }^{7}$. Geiogamah seeks to constitute Native Theatre as a unified content to study and creative growth in tribal colleges, Native communities and all other interested institutes, basing on Native views, customs, and perspective of spirituality, histories, culture, languages, communities and lands.

LeAnne Howe (2001) speaks of honouring the importance of community by creating Native theatre collectively. Howe and her collaborator Roxy Gordon scripted their play, Indian Radio Days, from impoverished work. The play retells history of America from a Native American perspective to both Native and non- Native people.

Family disruption caused by separation of children from their families under Pratt's educational policies and foster houses is another significant issue dealt with by Native American literature. Generally, the family of an individual is focus of a person's emotional life and attacks on Indian family setup through breakup contributes to the feeling of helplessness and impotency. In addition to experiencing the trauma of separation from their families, the displaced children are forced to adapt themselves to social and cultural surroundings which are completely different from their homes.

Drew Hayden Taylor (1962-) is one of Canada's most widely known Native playwrights, views playwrighting as a contemporary continuation of traditional story telling. He thinks of himself "as carrying on the tradition of storytelling that our elders shared with us." "Only Drunks and Children" by Drew Taylor shows that even if the efforts of foster parents were benevolent, Indian heritage transmission was not done adequately in case of the adopted children. Nubile children were thrust into an alien environment where they were taught to denigrate their previous ethos and normative guidelines. The denigration of their native culture bred in them split identities and double consciousness. The play is about the "scoop up" policy by $\mathrm{CAS}^{8}$ or taking of the native children for adoption in white society. In an appealing merger of comedy and pathos the play reveals the clash of cultures experienced by two sisters raised in two different environments. This play being a sequel to Someday accomplishes the task left unfinished in the previous play and brings about reconciliation between two sisters biologically related, yet socially alienated. Barb convinces her sister Janice to return to Otter Lake to pay her last respects to their recently deceased mother. Frightened of "opening injuries", Janice declines to visit the reservation but her younger sister Barb who is raised on reservation is unwilling to let go of her rancour. The double consciousness and clash of cultures of both sisters is placed side by side for comparison through their differences in English and Ojibway languages. Captivated between two different cultures and two languages subjects Janice to a trauma of the deracination, referred to as "un-homeliness" by Bhabha (2004). Janice's identity junctures has made her a psychological expatriate.

The play depicts truthfully Janice's search for identity. Grace/ Janice fluctuates to discover a place where her genetic roots can fertilise the essence of her present. To search for her identity, she puts in efforts to acquire a few words of her native language Ojibway. When she goes on the Reserve, Barb knots her into tribal existence when she hands her a dream catcher. Dream catchers are particularly important in a Native American perception as they "enable infants to see all good dreams and filter the nightmares or dreams of evil omen". This present carries the label that says, "Good dreams move through the netting, bad dreams are captured and dissolved by the early morning light." This tribal present is an eye opener for Janice who admits that she 
Politico-cultural appropriation of Native American in American Indian poetry and drama ...

should have come earlier to the Reserve. She confesses that she grew up hating her mother and thought that her rootlessness and displacement were her mother's fault. However, on meeting her mother she found a "fantastic, sweet and worrying mother that system had taken away her baby for no good reason". She later gets to know that her mother loved her too much and agitated to get back but the brutal federal policies kept them apart.

The drama adroitly positions Janice, a professional lawyer leading an urbanised luxurious life with her sister Barb who lives in destitution and has to face hardships after her father, brother and mother's deaths respectively. Her friends Rodney and Tonto are brought up by the tribal community. They both have only a rudimentary education but both of them revere community elders and usually converse in English with a few Ojibway words interspersed in their conversation. Capable of holding back the tribal traditions they make a deliberate effort to help Janice overcome her identity crises. In this they assume the role of tribal healers who stitch Janice's gashing wounds of belongingness. The play depicts that Janice is split psychologically between two diverse cultures. At the outset of the play, Barb, Rodney and Tonto notice both English and Indian items such as "A Maxine Noel", an "Odjig" and a "Roy Thomas" (208). Tonto remarks are pertinent as he says, "The woman is not as white as you thought." Genetically she is an Indian but culturally she inhabits a white world. This duality traps her all time but she achieves fulfilment when she pays her last respect to her dead mother at reservation.

Feryal Cubukcu (2013) is of the view that American Indian writers commit their affiliation with their tribal roots even though they are brought up in different environments and thus have different perception and emotions. American Indian writers might not have spent considerable time with their tribes and most of them have been brought up close to but not within the customs of their respective tribes. Still, they have managed to achieve a delicate creative balance between subjective point of view and an objective depiction of the native's problems. Outcome of blended culture and educated in mainstream institutions these writers successfully and interestingly coalesced mainstream literary custom and the tribal oral tradition. They have an edge of bearing healthy spiritual traditions, a sense of carrying tribal heritage and an awareness of their kinship to their roots. These writers depict characters suffering from a feeling of unhomliness; they are not certain of where they belong to. Only Drunks and Children presents "homing" as the opposite of competitive individualism, which is white success.

Denise (2007) writes in his Native American Literature, that the protagonist either seeks or is forced by others to seek a meaningful relation to their roots and land. He/she becomes a healthy person through accepted social ritual. Self-realization is associated with tribal reality which is profoundly conservative as progress and a fresh start away from the birth place is not endemic to American Indians. No "free individual" who achieves white success is really admired and the free mode of life is not preferred to tribal context. The protagonist seeks an identity that is anchored in his/her community. He/she can't find meaning in life being alone as individuality is not meaningful. Only Drunk and Children depict an Indian coming home and staying home, but "home" is not the "house of white heaven". Jenice/Grace succeeds largely to the degree in which she reinvigorates into the tribe, and fails largely to the degree in which she remains alone. The play is a pronounced criticism of modern European culture, blended with an unyielding denial to let go of tribal identity. The writer is not resurrecting archaic customs like dream catchers and condolence for symbolic purposes alone, but telling of the pull of tribal identity and tribal pride. Going back to roots is a healing process for Janice. 
Taylor's imagination is amusing and it appears that in the face of odds the only surviving tactic proposed by him is comedy as it is in accordance with an Indian vision of community. Taylor writes:

"I wish people to have belief that Natives don't live only for land claim, drunkenness and subjugation. I desire that they see us laughing and crying. They must know that we do have purgative moments. It's my earnest desire that spectators watch my plays to acknowledge the reality that we do possess multifaceted life. It's not only sorrows, gloominess and doom that they find in the media. It is our great sense of humour that allows us to endure the blacker facets of our history (Thomas: Noted in Bhatti, 2014).

This literary piece is a depiction of malevolent and premeditated attempt on part of USA govt to destroy Canada's original inhabitants. Govt destroyed two generations of aborigines in an effort to "absorb" their children into the conventional culture by putting them with white families or in boarding institutions. It affected people adversely. Their Language and culture were doomed. Children were pulled from the covers of their family unit. The degree of illtreatment was dreadful. The fabric of native society has been decelerating to amend. Taylor himself Ojibway, uses humour as effective medicine to cure injures and exhibit this story in palatable bites for native and non-native audiences likewise.

Disorganization was present in another form as well. Although other inmates were not separated from their families; the presence of alcoholic parents often produced instability in their lives. The family unit for these children was not characterized by secure routine; rather sanctuary of a home was complicated by frequent drinking bouts on the part of parents. William S and Yellow Robe Jr. (2007) graphically depict in The Independence of Eddie Rose how alcohol tore an Indian family structure. It shattered everything including the dreams that gave hope to a people. The playwrights present Eddie Jones who feels uprooted despite his repeated attempts to belong. Maufort (2010) states, "The play chronicles the protagonist's progressive liberation from the tyranny of his mother, Katherine, whose heavy drinking prevents Eddie and his sister Theia from experiencing the comforts of a true home." Lenny, Katherine's half cast lover, brutalises the children and even sexually abuses Theia. Eddie Jones, the protagonist of the play, strives to get independence and liberation from un-homeliness and depressing environment. In the concluding scene, Eddie leaves his mother, having achieved spiritual independence. Maufort (2010) sees mother's role here as First Nations' grip on American Indian identity of which it must get disentangled. Katherine's ambivalent relation to her son is symptomatic of the ambivalent relation of the USA with Native Americans. Katherine harbours concurrent feelings of love and hate towards her son Eddie: "my boy... my beautiful boy... my baby...” (48), and later she says, “then go! I won't stop you... we don’t need you” (49).

Apart from Katherine, many other characters are oscillating between contradictory feeling which is symptomatic of indecisive nature of people developed in a state of despondency. Even a hard core villain Lenny's brutality is rooted in the atrocity of the sexual violence he endured during his incarceration (89). Similarly Thelma feels deeply torn apart between the feelings of allegiance toward her sister and the recognition that Katherine hardly behaves like a decent mother. Eddie Jones desires a way out of the labyrinth of reservation grasp, but is torn between his desire to move with Mike to explore individualism which is a European concept studded with competition and materialism. The writer proposes that the way out of the labyrinth of 
Politico-cultural appropriation of Native American in American Indian poetry and drama ...

reservation is by re-establishing links with spirituality. Eddie's aunt Thelma leads Eddie towards spirituality by providing a rejuvenative spiritual character. Construed as a guardian of traditional values, the symbolic presence of the dead relative (grandmother) suggests the interpretation between everyday reality and the world of spirits. Indeed Eddie repeatedly likes to meditate on the grave of his grandmother. From her he gathers the energy that will lead him to his final epiphany. Thus the play asserts that Thelma establishes the importance of sacred ritual of smoke bath as a site of identity construction. Indeed she cuts and burns her braids as a way to re-establish bond with the tradition. Thus Thelma alludes to the creative potential of native traditions. Characteristically, the climactic scene occurring near the headstone of the grandmother, points towards psychological healing of Eddie, who finally repossesses a sense of cultural identity and belonging. Thelma performs purification of Eddie. She invites her nephew to wash himself in Sage smoke. This ritualistic ceremony contributes to the final mood of cultural affirmation. In the final scene Eddie boldly requires that his mother legally entrust guardianship of her children to Thelma. He demands that she sign an official complaint against Lenny. By breaking away with the umbilical cord of his mother drowned in alcoholism, he receives spirituality to reaffirm his connections with spirituality, a traditional Indian way of coming out of despondency.

N. Scott Momaday (2007) depicts adverse effects of Bratt's educational policies that strove to alienate Native Americans from their culture. Three Plays laurels American Indian cultural memory by bringing stories from Native American oral tradition. In Indolent Boys Momaday recounts the narration of three Kiowa boys who were forced to live in Boarding school where corporeal punishment was inflicted as a symbolic punishment on those students who refused to subscribe to White policies. The play challenges the stereotypes constructed by mainstream representation which presents natives as savages and brutal. On the contrary, Momaday (2007) presents a heroic picture of the boys who refuse to be subjugated and prefer death over a life of bondage. Even John Pai's character who is perceived as an emblem of the success of Indian Boarding school ("he is the personification of our mission", Gregory says, P 67) defies white rules whenever he gets an opportunity. He is as much distressed by the sad news of his "brothers' death in snow"(54), and rather than celebrating, he prefers to mourn with his people. The death of three native boys proves a crucial moment for John Pai who was initially in a doldrums as to which side to subscribe. But after the death of the boys, he joins the side of the camp and thus asserts his Indian identity.

Although proficient in white man's ways, Pai has always distrusted a system which taught the native children to "... slough our red skin, forget our languages, forget our parents and grandparents ... and our dead ancestors" (24). Boarding school was a site where a cumulative memory and past of a people was killed systematically through denigration and symbolic punishment and the learners were trained not to "remember but disremember" their culture and themselves and thus abandon any affiliation with their roots. Mommaday (2007) takes this responsibility to revive that memory and past in his plays. Momaday (2007) reanimates the memory of a pre-colonial matriarchal and communal set up in his play Children of the Sun where grandmother Spider narrates story of the creation of the world. The play is written for native children and has an instructive value for a new generation who has not seen glimpse of a glorious past. Hence the twins in a dialogue recount the history of Native America where the young and robust used to protect the feeble, the old, women and children. "There were times when buffalo and deer and antelope were plentiful, and no one was hungry and the children played in fields of wild flowers and they grew strong and laughed". Whereas in colonial period, 
there were times when buffalo and deer and antelope were scarce and starvation was frequent and in extreme cold weather children huddled and they were weak and wept.

\section{Conclusion}

The literature of Native American shows the impact of U.S. government imposed policies and strategies which created a virtual wasteland as far as American Indian identity is concerned. Various policies including displacing, relocating, enforced assimilation had drastic impact on the lives of Native Americans and the literature reflects the consequences of all those policies. Native American writers present a perfect image of meaningless existence akin to the ancient myth of Sisyphus who is doomed to roll a rock to the top of a mountain, only to see it roll back to the bottom, then to be rolled again to the top, whereupon it again rolls back to the foot of the mountain, endlessly through eternity. The lives of Indians resemble that of Sisyphus, and it makes no difference that they do not complain of it, their lives are consistent with servitude, entirely subject to the whim of others. But the literature by native writers does not only depict bleak picture, rather it makes readers/ audience conscious of their servitude and purports to awake them from torpidity. Native American literature moves one-step further than that. It engenders a ray of hope in the readers and audience to uplift them from a degraded situation and come out triumphant by asserting their Indian heritage and becoming proud nation.

\section{References}

Alexie, S. (1996). The summer of black widows. Hanging Loose.

Alexie, S. (2000). One stick song. Hanging Loose.

Bachman, R. (1991). The social causes of American Indian homicide as revealed by the life experiences of thirty offenders. American Indian Quarterly, 15(4), 469-492. https://doi.org/10.2307/1185365

Bhabha, H. K. (2004). The Location of Culture. Routledge.

Allen, P. (1996). "Introduction" in Songs of the Turtle: American Indian Literature 1974-1994. Ballantine.

Bachman, R. (1992). Death and Violence on the Reservation: Homicide, Family Violence, and Suicide in American Indian Population. Greenwood.

Bhatti, S. (2014). "Healing and the Environment in American Indian Biographies" European Scientific Journal, 10(8). 287-296.

Coulombe, J. (2002). The approximate Size of his Favourite Humour: Sherman Alexie's Comic Connections and Disconnections in the Lone Ranger and Tonto Fist Fight in Heaven. The American Indian Quarterly 26(1), 99-115.

Cubukcu, F. (2013). "Alternatives in Only Drunks and Children Tell the Truth." Ataturk Universitesi Sosyal Bilimler Enstitutusu Dergisi. 17(2): 97-104.

Dennis, H. (2007). Native American Literature: Towards a Spatialized Reading. Routledge.

Durkheim, E. (2010). Suicide: A Study in Sociology. IL Free.

Edmunds, D. (2001). "Introduction" in the New Warriors. Edt. R. David Edmunds. University of Nebraska. 1-14

Fixico, D. (2006). Daily Life of Native Americans in the Twentieth Century. Greenwood.

Hobson, G. (2000). "Native American Literature: Remembrance, Renewal." U.S. Society and Values. Contemporary U.S. Literature: Multicultural Perspective, Department of State, International Information Program. 
Politico-cultural appropriation of Native American in American Indian poetry and drama ...

Howard, H. (1979). American Indian Poetry. Twayne.

Huugo, A. (2007). "American Indian Theatre" in The Cambridge Companion to Native American Literature. Edt. Joy Porter and Keneth M. Roemer. Cambridge University. 189-212.

La Duke, C, W. (1985). "Native America: The Political Economy of Radioactive Colonization". Journal of Ethnic Studies, 13(3), 107-132.

Lincoln, K. (1985). Native American Renaissance. University of California.

Lincoln, K. (2010). Indi'n Humour: Bicultural play in Native America. In Maufort, Marc. Labyrinth of Hybridities: Avatars of O'Neillian Realism in Multiethnic American Drama (1972-2003). PI.E. Peter Lang.

Momaday, N. S. (2007). Three Plays. University of Oklahoma: Norman.

Stanlake, C. (2000). "Seventh Generation: An Anthology of Native American Plays". (Review). Theatre Journal 52(2), 144-145.

Swann, K, A. (1987). I Tell you Now. Autobiographical essays by Native American Writers. University of Nebraska.

\section{Notes:}

\footnotetext{
${ }^{1}$ A reservation is an area of land set aside for use by a Native American Tribe. In mid- $19^{\text {th }}$ century, American government embarked on a plan of restraint as a means of controlling the Indians and encouraging Westward expansion. Military force was employed to discipline lots of clans and resettle them on Westward reservations, where they lived till the time new colonies projects or the exploration of oil and precious minerals resulted in farther displacement. Almost all genuine clans' nations were either disunited or immersed into other groups if not annihilated altogether.

${ }^{2}$ Dawes' Act was a major piece of legislation which changed the fabric of Indian family and cultural norms in a tremendously negative way. The Act determined that at the president's discernment almost all reservations would be divided into small (160 acre) farms and divided amongst individual Native Americans. The Act stipulated that was not mandatory, and citizenship would be granted to those Indians who adhere to the Act.

${ }^{3}$ The term Native American Renaissance was coined by critic Kenneth Lincoln in Native American Renaissance (1983) to categorize the significant increase in production of literary works by Native Americans in the US in the late 1960s onward.

4 "Inside Song" is a term used by Helen Howard in American Indian Poetry, which refers to another peculiarity of Indian poetry. Words can never fully express the full meanings of a poem, so words are used only as a shorthand mark to "inside song". The inside story might be a long story, a myth, or a dramatic episode which gives rise to the musical dance. Thus, a significant part of the narrator's life experience or adventure may be depicted in a small sentence, yet; to comprehend the poem, the story or episode behind the poem must be known thoroughly.

${ }^{5}$ Chair, here refers to an electric Chair used for electrocution

${ }^{6}$ NATE is abbreviation of Native American Theatre Ensemble, established by Hanay Geiogmah in 1972. In NATE's premier performance Body Indian was performed in October of 1972. Geiogmah wrote this twoAct play for the company. Geiogmah wanted to use theatre to bring consciousness about cultural and political and social problems of native audience.

${ }^{7}$ HOOP stands for Honouring Our Origins and People through Native Theatre, Education and Community Development. With NATE Geiogamah had sought to bring theatre to Reservation communities and to foster the growth of Native Theatre Companies, around the country. HOOP continues that effort at bigger stage.

${ }^{8}$ Children's Aid Society
} 